\title{
Al-Ni-Ta-V (Aluminum-Nickel-Tantalum-Vanadium)
}

\section{Raghavan}

Several polyphase eutectic alloys with a metallic phase and one or more ordered intermetallics in the microstructure were examined by [1995Joh] in an effort to obtain a good combination of room-temperature toughness and hightemperature strength. The characteristics of the NiAlNiAlTa- $\mathrm{V}$ eutectic mixture of this quaternary system were studied in this connection.

\section{Binary Systems}

For brief descriptions of the $\mathrm{Al}-\mathrm{Ni}, \mathrm{Al}-\mathrm{Ta}$, and $\mathrm{Ni}-\mathrm{Ta}$ phase diagrams, see the Al-Ni-Ta update in this issue. See [2005Rag] for descriptions of the Al-V and Ni-V phase diagrams. The Ta-V phase diagram [Massalski2] depicts a continuous body-centered-cubic solid solution between Ta and V. An intermediate phase $\mathrm{V}_{2} \mathrm{Ta}$ forms below $1310^{\circ} \mathrm{C}$ and has the $\mathrm{MgCu}_{2}$-type cubic structure.

\section{Ternary Systems}

An update on the Al-Ni-Ta system appears in this issue. The update of the Al-Ni-V system by [2005Rag] includes partial isothermal sections at 1300 and $1200{ }^{\circ} \mathrm{C}$ and a vertical section along the $\mathrm{Ni}_{3} \mathrm{Al}-\mathrm{Ni}_{3} \mathrm{~V}$ join. The compilation of [1995Vil] presented an isothermal section at $1000{ }^{\circ} \mathrm{C}$ for the Al-Ta-V system. The Ni-Ta-V system reviewed by [1991Gup] reported the lack of phase diagram data in the system.

\section{Quaternary Phase Equilibria}

Using high-purity Al, Ni, Ta, and V metals, [1995Joh] prepared alloy compositions by induction and arc melting. By metallographic examination, four compositions were bracketed to yield the maximum volume fraction of the eutectic mixture. The microstructure of the directionally solidified alloy showed vanadium-rich dendrites surrounded by cells or colonies of the ternary eutectic of NiAl-NiAlTa-V. The tentative liquidus projection constructed by [1995Joh] is shown in Fig. 1 on a triangular section of the composition

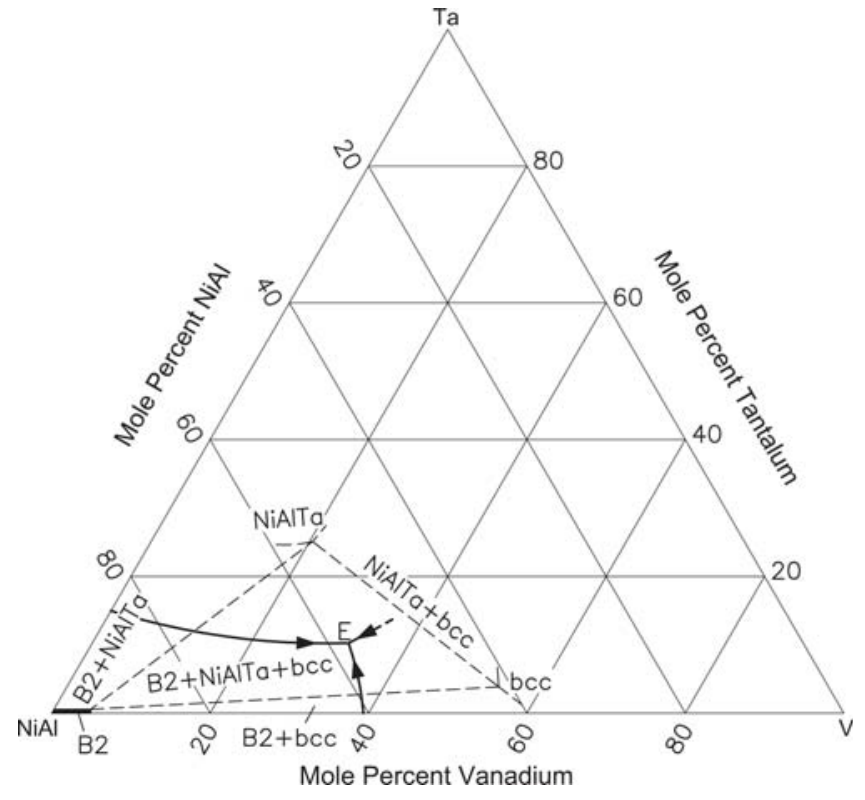

Fig. 1 Al-Ni-Ta-V partial liquidus projection on the NiAl-V-Ta plane [1995Joh]

tetrahedron obtained by joining $\mathrm{NiAl}$ to $\mathrm{Ta}$ and $\mathrm{V}$ corners. The phase distribution at the undetermined eutectic temperature is shown schematically in Fig. 1. E is the composition of the eutectic liquid.

\section{References}

1991Gup: K.P. Gupta, The Ni-Ta-V (Nickel-TantalumVanadium) System, Phase Diagrams of Ternary Nickel Alloys. Part 2, Ind. Inst. Metals, Calcutta, 1991, p 208-213

1995Joh: D.R. Johnson, B.F. Oliver, R.D. Noebe, and J.D. Whittenberger, NiAl-Based Polyphase in situ Composites in the NiAl-Ta- $X$ ( $X=$ Cr, Mo, or V) Systems, Intermetallics, 1995, 3, $\mathrm{p}$ 493-503

1995Vil: P. Villars, A. Prince, and H. Okamoto, Al-Ta-V, Handbook of Ternary Alloy Phase Diagrams, Vol 4, ASM International, 1995, p 4360-4364

2005Rag: V. Raghavan, Al-Ni-V (Aluminum-Nickel-Vanadium), J. Phase Equilibria, 2005, 26(3), p 273-275 